\title{
Autour d'un concept : "L'alimentation méditerranéenne"
}

Annie Hubert

\section{(2) OpenEdition}

1 Journals

Édition électronique

URL : https://journals.openedition.org/tc/390

DOI : $10.4000 /$ tc. 390

ISSN : 1952-420X

Éditeur

Éditions de l'EHESS

\section{Édition imprimée}

Date de publication : 1 avril 1999

ISSN : 0248-6016

\section{Référence électronique}

Annie Hubert, "Autour d'un concept : "L'alimentation méditerranéenne" », Techniques \& Culture [En ligne], 31-32 | 1999, mis en ligne le 26 octobre 2005, consulté le 29 septembre 2022. URL : http:// journals.openedition.org/tc/390 ; DOI : https://doi.org/10.4000/tc.390

Ce document a été généré automatiquement le 29 septembre 2022.

Tous droits réservés 


\section{Autour d'un concept : "L'alimentation méditerranéenne"}

Annie Hubert 